\title{
Порівняння ефективності охолодження повітря на вході газотурбін- ного двигуна в умовах помірного і субтропічного клімату
}

\author{
А. М. Радченко ${ }^{1}$, Я. Зонмін ${ }^{2}$, С. А. Кантор ${ }^{3}$, Б. С. Портной ${ }^{1}$ \\ ${ }^{1}$ Національний університет кораблебудування ім. адм. Макарова, м. Миколаїв, 54002, Україна \\ ${ }^{2}$ Цзянсуньський університет науки і технології, м. Чженьцзян, КНР \\ ${ }^{3}$ ПАТ "Завод "Екватор", м. Миколаїв, Україна
}

\begin{abstract}
Проаналізовано охолодження повітря на вході газотурбінного двигуна при змінних упродовж року кліматичних умовах експлуатації. Запропоновано для охолодження повітря застосування тепловикористовуючих холодильних машин, щчо використовують для отримання холоду теплоту відпрацьованих газів газотурбінного двигуна. Досліджено ефективність охолодження повітря на вході газотурбінного двигуна в абсорбиійній бромистолітієвій холодильній машині до температури $15^{\circ} \mathrm{C}$ та у двоступінчастій абсорбиійно-ежекторній холодильній машині до $10^{\circ} \mathrm{C}$. Хладонова ежекторна холодильна машина вибрана як конструктивно найбільш проста і надійна в експлуатації. При изьому абсорбиійна бромистолітієва холодильна машина використовується в якості першого високотемпературного ступеня попереднього охолодження зовнішнього повітря від його поточних температур до $15^{\circ} \mathrm{C}$, а хладонова ежекторна машина - як другий низькотемпературний ступінь його доохолодження до $10^{\circ} \mathrm{C}$. Ефективність охолодження повітря проаналізована для експлуатації в умовах характерного для України помірного клімату і субтропічного клімату (на прикладі КНР). Як показник використано зменшення витрати палива. Показано, шуо охолодження повітря на вході газотурбінного двигуна для субтропічного клімату забезпечує у 1,6...1,8 рази більшу економію палива порівняно з умовами помірного клімату. Однак більш глибоке охолодження повітря на вході газотурбінного двигуна до температури $10^{\circ} \mathrm{C}$ в абсорбиійноежекторній холодильній машині порівняно з температурою охолодження повітря $15^{\circ} \mathrm{C}$ в абсорбиійній бромистолітієвій холодильній машині забезпечує більше скорочення витрати палива для умов помірного клімату ніж для субтропічного клімату. Показано, щзо якщо для умов помірного клімату його контактне охолодження $i$ забезпечує економію палива близьку до ї̈ величини при охолодженні до температури $15^{\circ} \mathrm{C}$ в абсорбиійній бромистолітієвій холодильній машині, то для субтропічного вологого клімату воно практично не дає ефекту.
\end{abstract}

Ключові слова: Охолодження повітря; Холодильна машина; Клімат; Газотурбінний двигун.

(C) The Author(s) 2018. This article is an open access publication

This work is licensed under the Creative Commons Attribution 4.0 International License (CC BY) http://creativecommons.org/licenses/by/4.0/

\section{1. Аналіз проблеми і постановка мети дослідження}

Ефективність газотурбінних двигунів (ГТД) при високих температурах зовнішнього повітря $t_{3 п}$ на вході знижується. Так для ГТД виробництва ДП НВКГ "Зоря"-"Машпроект" з підвищенням температури зовнішнього повітря $t_{3 п}$ на вході на $10^{\circ} \mathrm{C}$ питома витрата палива $b_{e}$ зростає на $5 \ldots 8$ г/(кВт-год), а потужність $N_{e}$ зменшується на $5 \ldots 8 \%[1,2]$. Оскільки температура відпрацьованих газів вельми висока і для ГТД простого циклу становить $450 \ldots 500{ }^{\circ} \mathrm{C}$, то доцільним $є$ охолодження повітря на їх вході тепловикористовуючими холодильними машинами (ТХМ), що утилізують скидну теплоту газів [3, 4].

Ефективність застосування охолодження повітря на вході ГТД залежить від температури зовнішнього повітря $t_{3 п}$, яка суттєво змінюється упродовж року і в різних регіонах може дуже відрізнятися.

Мета роботи - аналіз ефективності охолодження повітря на вході газотурбінного двигуна тепловикористовуючими холодильними машинами в умовах помір- ного, характерного для України більшості європейських країн, і субтропічного клімату.

\section{2. Результати дослідження}

При експлуатації ГТУ тепловологісні параметри зовнішнього повітря (температура $t_{3 п}$ та відносна вологість $\varphi_{3 п}$ ) зазнають суттєвих змін. Як приклад, на рис. 1 і 2 представлено зміну температури $t_{3 п}$, відносної вологості $\varphi_{3 п}$ та вологовмісту $d_{3 п}$ зовнішнього повітря упродовж 2017 року та липня для м. Вознесенськ, Україна (помірний клімат), та м. Нанкін, КНР (субтропічний клімат). Особливістю субтропічного клімату $є$ велика відносна вологість повітря $\varphi_{3 п}$, відповідно й вологовміст $d_{3 п}$ при водночас високих його температурах $t_{3 п}$ (рис. 1,б). Це свідчить про значну частку прихованої теплоти конденсації водяної пари 3 повітря, яку треба відводити при його охолодження, відповідно й про великі теплові навантаження (витрати холодопродуктивності ТХМ) на систему охолодження повітря на вході газотурбінного двигуна. 

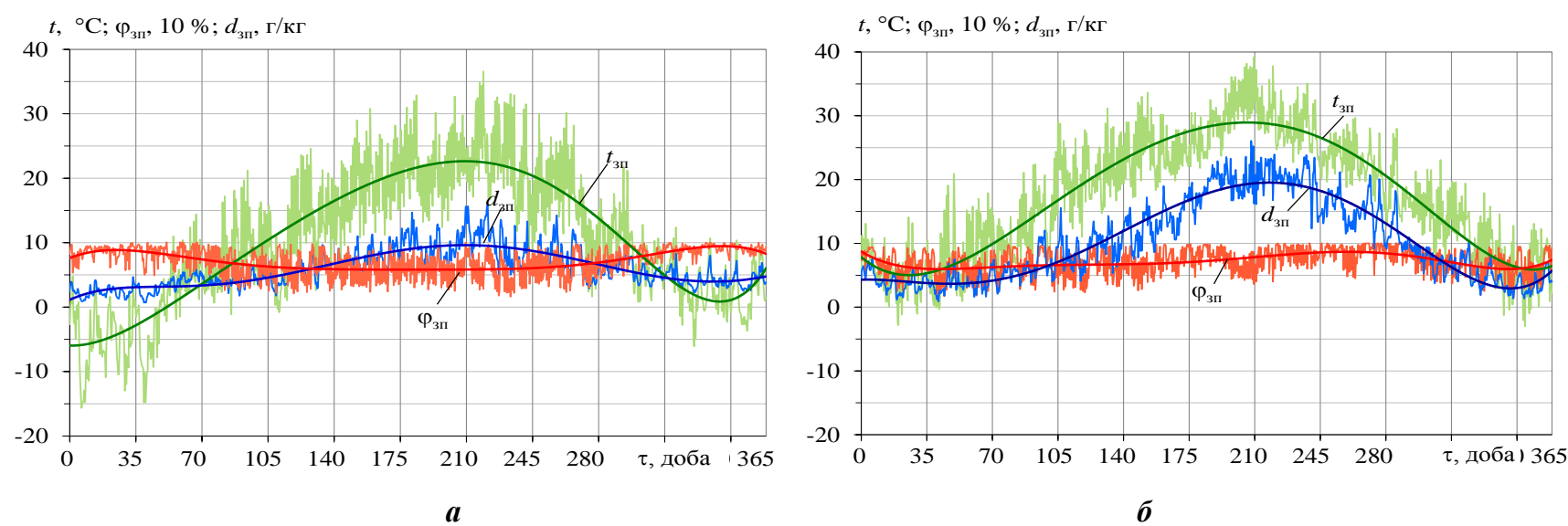

Рисунок 1 - Поточні значення температури $t_{3 n}$, відносної вологості $\varphi_{3 n}$ та вологовмісту $d_{3 n}$ зовнішнього повітря у 2017 рочі: $\boldsymbol{a}$-м. Вознесенськ, Миколаӥвська обл., Украӥна; б-м. Нанкін, КНР
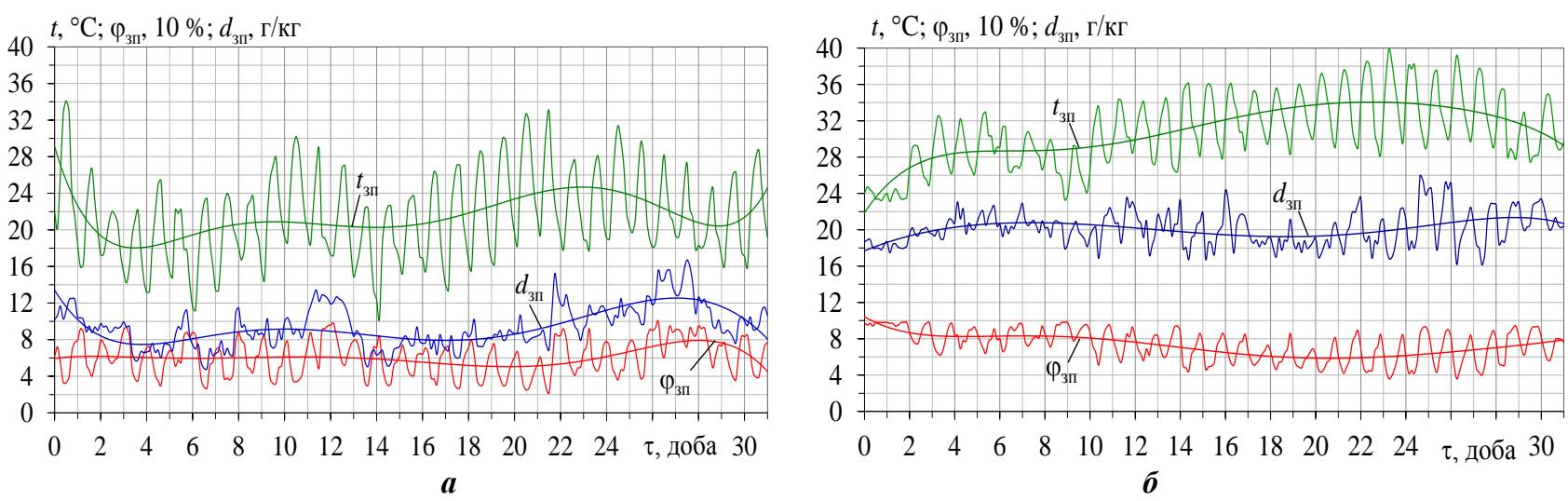

Рисунок 2 - Поточні значення температури $t_{3 n}$, відносної вологості $\varphi_{3 n}$ та вологовмісту $d_{3 n}$ зовнішнього повітря у липні 2017 року: $\boldsymbol{a}-$ м. Вознесенськ, Україна; б-м. Нанкін, КНР

Для охолодження зовнішнього повітря до температури $t_{\Pi 2}=15^{\circ} \mathrm{C}$ на вході ГТУ застосовано абсорбційну бромистолітієву холодильну машину (АБХМ), для більш глибокого охолодження зовнішнього повітря двоступеневу абсорбційно-ежекторну холодильну машину (AЕXМ) з АБХМ в якості високотемпературного ступеня попереднього охолодження зовнішнього повітря до температури $t_{\text {п2 }}=15^{\circ} \mathrm{C}$ та хладоновою ежекторною холодильною машиною (ЕХM) подальшого глибокого охолодження до $10^{\circ} \mathrm{C}$ і нижче) [5].

Про поточні упродовж липня значення зменшення питомої витрати палива $\Delta b_{e 15}$ в результаті охолодження повітря на вході ГТД від $t_{3 п}$ до $t_{\text {п2 }}=15^{\circ} \mathrm{C}$ на величину $\Delta t_{15}$ в АБХМ, а також $\Delta b_{e 10}$ при охолодженні повітря від $t_{3 п}$ до $t_{\text {п2 }}=10{ }^{\circ} \mathrm{C}$ на величину $\Delta t_{10}$ в AЕXМ для умов помірного клімату (м. Вознесенськ, південь України) та субтропічного клімату (м. Нанкін, КНР) можна судити по рис. 3 i 4. Розрахунки виконані для ГТД UGT 10000 ДП НВКГ "Зоря"-"Машпроект" потужністю 10 МВт, для яких зниження температури повітря $\Delta t_{\text {п }}$ на $1{ }^{\circ} \mathrm{C}$ приводить до зменшення питомої витрати палива $\Delta b_{e}$ на 0,7 г/(кВт·год).
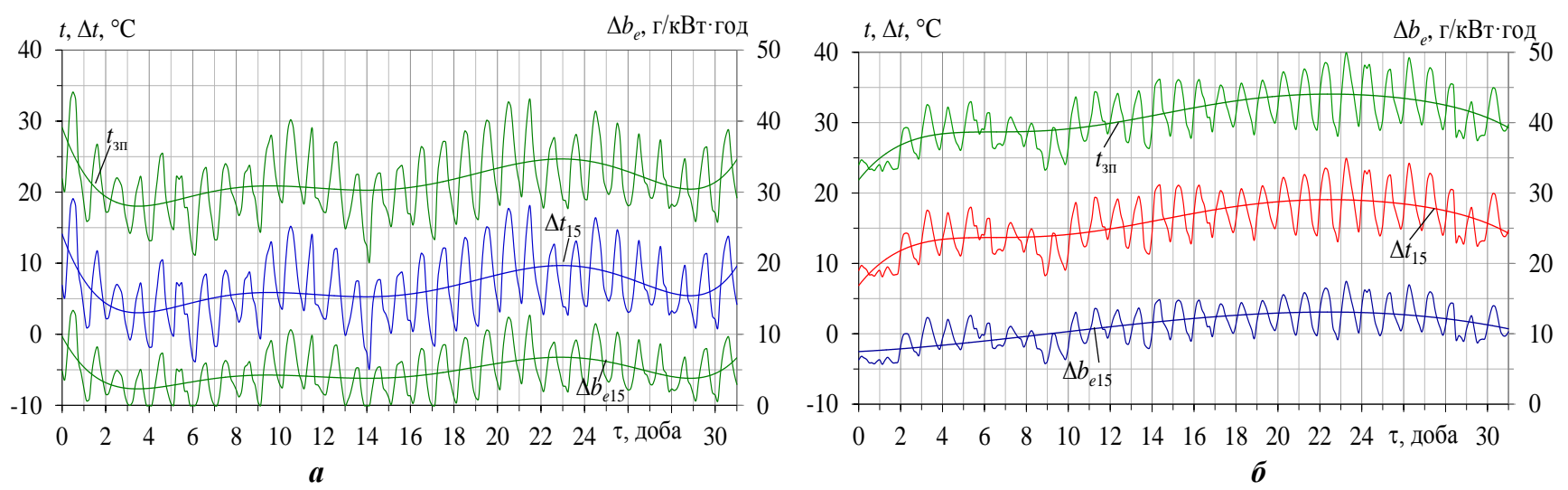

Рисунок 3 - Поточні значення температури $t_{3 n}$ зовнішнього повітря, зниження температури зовнішнього повіт-

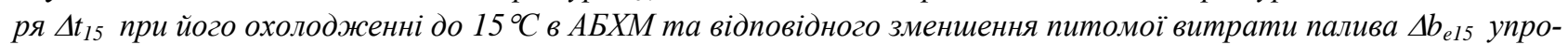
довж липня 2017 року: $\boldsymbol{a}-$ м. Вознесенськ, Украӥна; б-м. Нанкін, КНР 
Як видно з рис. 3, охолодження повітря на вході UGT 10000 від поточної температури зовнішнього повітря $t_{\text {зп }}$ до $15{ }^{\circ} \mathrm{C}$ в АБХМ забезпечує поточне зменшення питомої витрати палива $\Delta b_{\mathrm{e} 15}=4 \ldots 8$ г/(кВт·год) для умов м. Вознесенськ (помірний клімат, рис.3, a), тоді як для м. Нанкін, КНР (субтропічний клімат, рис.3, б) близько $10 \ldots 11$ г/(кВт·год).

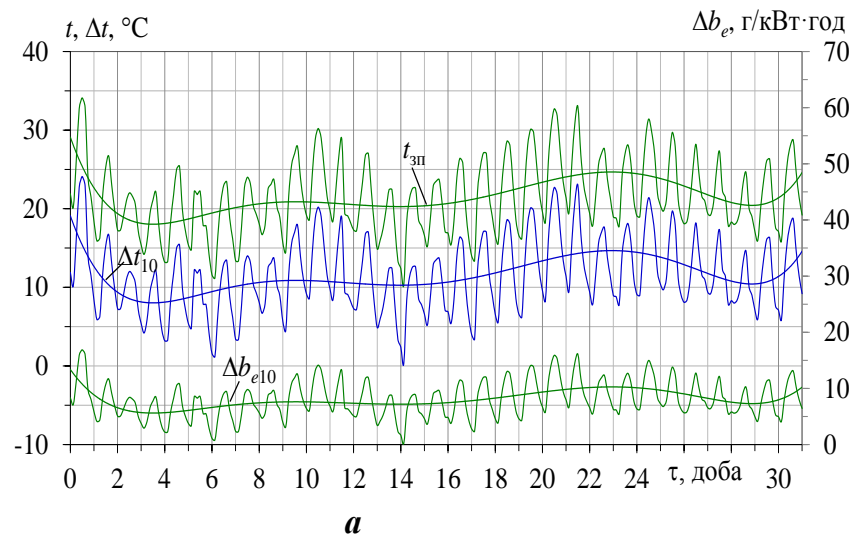

Глибоке ж охолодження повітря двоступеневою $\mathrm{AEXM} \mathrm{до} 10^{\circ} \mathrm{C}$ дає можливість отримати більше поточне скорочення питомої витрати палива $\Delta b_{e 10}$ : $7 \ldots 11$ г/(кВт·год) і понад $12 \ldots 15$ г/(кВт·год) відповідно для умов м. Вознесенськ (рис.4, a) і м. Нанкін, КНР (рис.4, б).

Рисунок 4 - Поточні значення температури $t_{3 n}$ зовнішнього повітря, різниці температур зовнішнього повітря та

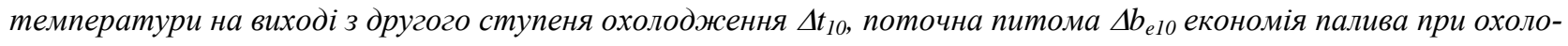
дженні повітря до $10^{\circ} \mathrm{C}$ за липень 2017 року; $\boldsymbol{a}-$ м. Вознесенськ, Україна; б -м. Нанкін, КНР

Необхідно зазначити більше поточне скорочення питомої витрати палива $\Delta b_{e 10}$ за рахунок глибшого охолодження повітря на вході ГТД в АЕХМ до $t_{\text {п2 }}=10^{\circ} \mathrm{C}$ порівняно з його охолодженням в АБХМ до $t_{\text {п2 }}=15^{\circ} \mathrm{C}$. Проте позитивний ефект буде дещо менший через витрати палива ГТД для подолання аеродинамічного опору повітроохолоджувача на вході.

Більш глибоке охолодження повітря на вході ГТД до температури $t_{\text {п2 }}=10^{\circ} \mathrm{C}$ в AЕХМ забезпечує сумарне за липень зменшення питомої витрати палива $b_{e \_\Sigma 10}$ близько 6 кг/кВт (віднесене до 1 кВт потужності ГТД) для помірних кліматичних умов (рис.5, a) і близько 11 кг/кВт для субтропічного клімату (рис.5, б). При цьому застосування глибокого охолодження повітря до температури $t_{\text {п2 }}=10^{\circ} \mathrm{C}$ в $\mathrm{AEXM} \mathrm{дає} \mathrm{навіть} \mathrm{більший}$ ефект у порівнянні 3 охолодженням в АБХМ до $t_{\text {п2 }}=15^{\circ} \mathrm{C}$ та контактним охолодженням повітря (упорскуванням у нього води) до температури мокрого термометру за помірного клімату (рис. 5,a) ніж субтропічного клімату (рис. 5,a).

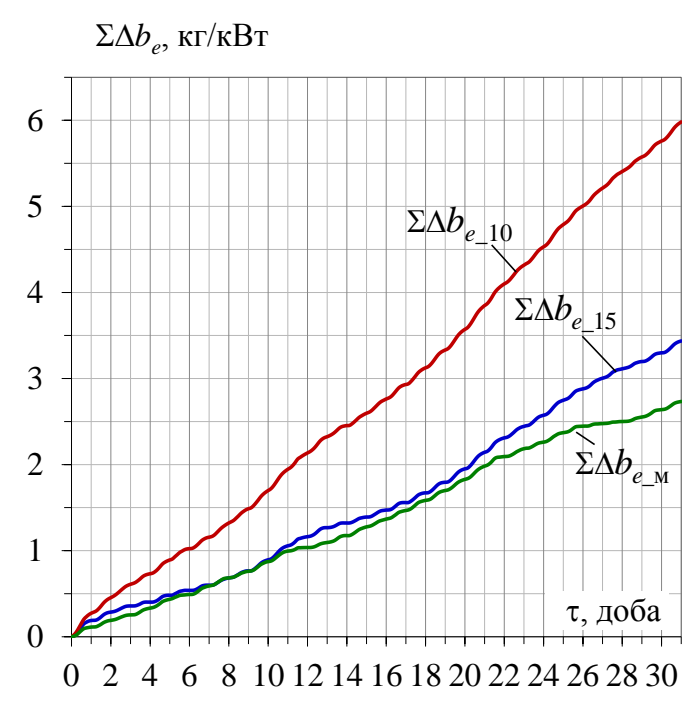

$a$

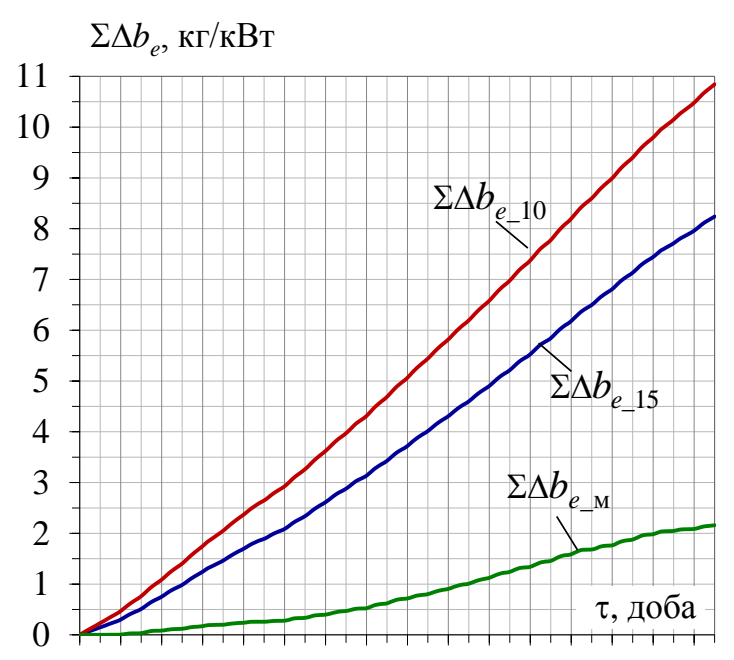

$0 \quad 2 \quad 4 \quad 6 \quad 8 \quad 1012141618202224262830$ б

Рисунок 5 - Значення сумарного за липень зменшення питомої витрати палива $\Sigma \Delta b_{e}$ при різних температурах охолодженого повітря $t_{n 2}: 10{ }^{\circ} \mathrm{C}-A E X M ; 15{ }^{\circ} \mathrm{C}-$ АБХМ-ступінь, м-контактне охолодження повітря упорскуванням води до температури мокрого термометра за липень 2017 року: $\boldsymbol{a}$-м. Вознесенськ; б - м. Нанкін, КНР 
Про сумарну за накопиченням питому економію палива $\Sigma \Delta b_{e 15}$ i $\Sigma \Delta b_{e 10}$, що припадає на 1 кВт потужності ГТД, за рахунок охолодження повітря на вході ГТД UGT 10000 (потужністю 10 МВт) від поточної темпера- тури зовнішнього повітря $t_{3 п}$ до $15^{\circ} \mathrm{C}$ в АБХМ і до $10{ }^{\circ} \mathrm{C}$ в АЕХМ на протязі 2017 року можна судити по рисункам 6 і 7.
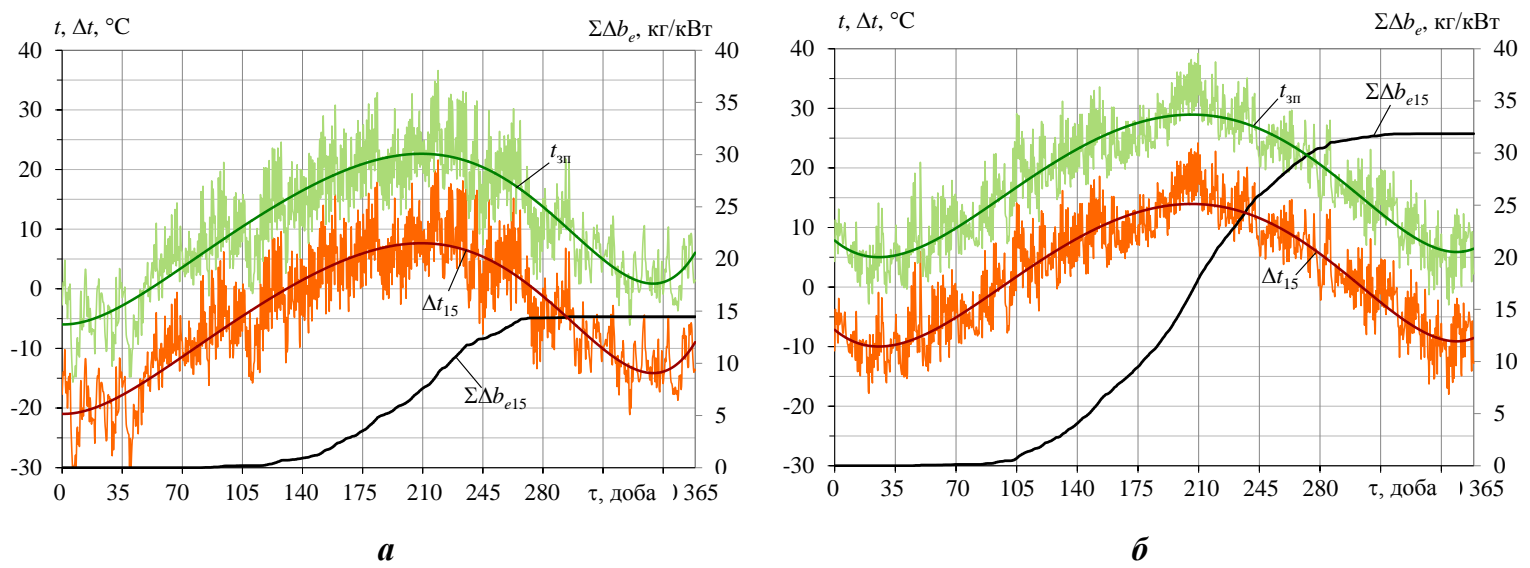

Рисунок 6 - Поточні значення температури $t_{3 п}$ зовнішнього повітря, зниження температури $\Delta t_{15}$ зовнішнього повітря при його охолодженні до $t_{\text {п2 }}=15^{\circ} \mathrm{C}$ на вході ГТД в АБХМ, відповідної сумарної за накопиченням питомої економії палива $\Sigma \Delta b_{e 15}$, що припадає на 1 кВт потужності ГТД, на протязі 2017 року:

$\boldsymbol{a}$ - м. Вознесенськ, Україна; $\boldsymbol{\sigma}$ - м. Нанкін, КНР
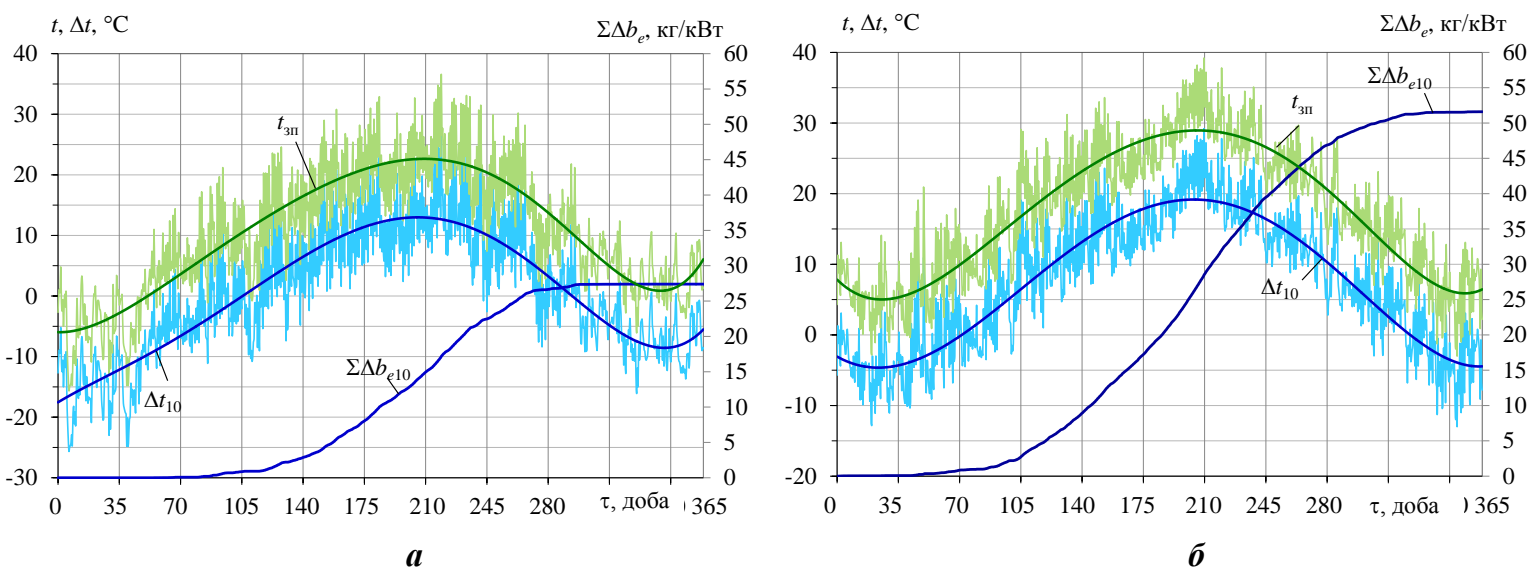

Рисунок 7 - Поточні значення температури $t_{3 п}$ зовнішнього повітря, зниження температури $\Delta t_{10}$ зовнішнього повітря при його охолодженні до $t_{\text {п2 }}=10^{\circ} \mathrm{C}$ на вході ГТД в АЕХМ, відповідної сумарної за накопиченням питомої економії палива $\Sigma \Delta b_{e 10}$, що припадає на 1 кВт потужності ГТД, на протязі 2017 року: $\boldsymbol{a}$ - м. Вознесенськ, Україна; б - м. Нанкін, КНР

Як видно 3 рис. 6 , охолодження повітря на вході UGT 10000 до $15^{\circ} \mathrm{C}$ в АБХМ забезпечує річну питому економію палива $\Sigma \Delta b_{e 15}$ близько 14 кг/кВт (на 1 кВт потужності ГТД) для умов помірного клімату (м. Вознесенськ, рис.6,a), тоді як для субтропічного клімату (м. Нанкін, КНР, рис.6,б) понад 32 кг/кВт. В той же час більш глибоке охолодження повітря в $\mathrm{AEXM} \mathrm{до} 10^{\circ} \mathrm{C}$ дає змогу отримати набагато більшу питому економію палива за рік $\Sigma \Delta b_{e 10}: 27$ кг/кВт і понад 50 кг/кВт відповідно для умов помірного (рис.7,a) i субтропічного клімату (рис.7,б). Звертає на себе увагу більш значне збільшення питомої річної економії палива $\Sigma \Delta b_{e 10}$ за рахунок більш глибокого охолодження повітря на вході ГТД в АЕХМ до $t_{\text {п2 }}=10^{\circ} \mathrm{C}$ порівняно 3 його охолодженням в АБХМ до $t_{\text {п2 }}=15^{\circ} \mathrm{C}: 27 \mathrm{\kappa г} / \mathrm{\kappa ВТ}$ проти 14 т/кВт, тобто майже вдвічі. Варто зазначити, що через витрати потужності ГТД, відповідно й палива, на подолання аеродинамічного опору повітроохолоджувача на вході реальна економія палива буде дещо меншою.

\section{3. Висновки}

Проаналізовано ефективність охолодження повітря на вході ГТД для умов помірного клімату, характерного для України (на прикладі кліматичних умов м. Вознесенськ, південь України) та м. Нанкін, КНР (субтропічний клімат) в АБХМ до $15^{\circ} \mathrm{C}$ і в АЕХМ до $10^{\circ} \mathrm{C}$ для літнього місяця.

Показано, що хоча в цілому більшу економію палива при охолодженні повітря на вході ГТД отримують для умов субтропічного клімату у порівнянні з помірним, однак більш глибоке охолодження повітря на вхо- 
ді ГТД в АЕХМ до температури $t_{\text {п2 }}=10^{\circ} \mathrm{C}$ порівняно 3 його охолодженням в АБХМ до $t_{\text {п2 }}=15^{\circ} \mathrm{C}$ для умов характерного для України помірного клімату дає більше прирощення річного ефекту ніж для субтропічного клімату, що свідчить про необхідність застосування технологій саме глибокого охолодження повітря на вході з метою поліпшення паливної економічності двигунів.

\section{Література}

1. Erdem, H. H. Case study: Effect of ambient temperature on the electricity production and fuel consumption of a simple cycle gas turbine in Turkey [Text] / Hasan Huseyin Erdem, Suleyman Hakan Sevilgen. - Applied Thermal Engineering. - 2006. - №26. - pp. 320 - 326.

2. Николаевские газовые турбины промышленного применения. - Николаев: ГП НПКГ "Заря""Машпроект", 2004. - 19 с.

3. Соколов, Е.Я. Энергетические основы трансформации тепла и процессов охлаждения [Текст] / Е.Я. Соколов, В.М. Бродянский. - М.: Энергоиздат, 1981. - 320 с. 4. Ghaebi, H. Integration of an absorption chiller in a total CHP site for utilizing its cooling production potential based on R-curveconcept [Text] / H. Ghaebi, Sh. Karimkashi, M.H. Saidi // International journal of refrigeration. - 2012. - V.35 - pp. 1384-1392.

5. Радченко, А. Н. Метод выбора рациональной тепловой нагрузки абсорбционно-эжекторного термотрансформатора охлаждения воздуха на входе регенеративных ГТУ компрессорных станций [Текст] / А. Н. Радченко, С. А. Кантор // Авиационно-космическая техника и технология. - 2015. - № 5(122). - С. 61 - 64.

\title{
Comparing the efficiency of gas turbine engine intake air cooling in moderate and subtropical climate
}

\author{
A. N. Radchenko ${ }^{1}$, Y. Zongming ${ }^{2}$, S. A. Kantor ${ }^{3}$, B. S. Portnoi ${ }^{1}$ \\ ${ }^{1}$ Admiral Makarov National University of Shipbuilding, Mykolaiv, Ukraine \\ 2 Jiangsu University of Science and Technology, School of Energy and Power, Zhenjiang, China \\ ${ }^{3}$ PJSC "Zavod "Ekvator", Mykolaiv, Ukraine
}

\begin{abstract}
Air cooling at the gas turbine engine inlet was investigated for climatic conditions changed during the year. The use of waste heat recovery chillers, which use the heat of gas turbine engine exhaust gas to produce a cold has been proposed for air cooling. The efficiency of air cooling at the inlet of gas turbine engine to various temperatures was analyzed: in absorption lithium-bromide chiller down to $15{ }^{\circ} \mathrm{C}$ and in a two-stage absorption-ejector chiller down to $10^{\circ} \mathrm{C}$. In this case the absorption lithium-bromide chiller is used as the first high-temperature pre-cooling stage of ambient air from its current temperatures to $15^{\circ} \mathrm{C}$, and the refrigerant ejector chiller is used as the second low-temperature stage for its further subcooling to $10^{\circ} \mathrm{C}$. The refrigerant ejector chiller is chosen as the most simple and reliable in operation. The efficiency of air cooling is analyzed for operation in conditions of moderate continental climate peculiar to Ukraine and subtropical climate (People Republic of China). The fuel saving is used as an indicator. It is shown that the cooling of the air at the inlet of gas turbine engine for a subtropical climate provides 1.6...1.8 times more fuel saving compared to the conditions of a temperate climate. However, a deeper cooling of the air inlet of gas turbine engine to the temperature of $10{ }^{\circ} \mathrm{C}$ in an absorption-ejector chiller compared to the air cooling temperature of $15{ }^{\circ} \mathrm{C}$ in an absorption lithium-bromide chiller provides a more significant increase in fuel saving for temperate climate, than for a subtropical climate. It is shown, that if for conditions of a temperate climate the evaporation cooling of the air provides a fuel saving close to its value when cooled to the temperature of $15^{\circ} \mathrm{C}$ in absorption lithium-bromide chiller, then for a subtropical humid climate it has no any effect.
\end{abstract}

Keywords: Air cooling; Chiller; Gas turbine engine, Climate

\section{References}

1. Erdem, H. H., Sevilgen S. H. (2006). Case study: Effect of ambient temperature on the electricity production and fuel consumption of a simple cycle gas turbine in Turkey. Applied Thermal Engineering, no. 26, 320-326.

2. Nikolaev gas turbines for industrial applications. Nikolaev: State Enterprise NPKG "Zarya"-"Mashproekt", 2004, $19 \mathrm{p}$.

3. Sokolov, E. Ya, Brodyansky, V. M. (1981). Energy basics of heat transformation and cooling processes. Moscow: Energoizdat, 320 p.
4. Ghaebi, H., Karimkashi, Sh., Saidi, M. H. (2012). Integration of an absorption chiller in a total CHP site for utilizing its cooling production potential based on Rcurveconcept. International journal of refrigeration. vol. 35, 1384-1392.

5. Radchenko A. N., Kantor, S. A. (2015). The method of evaluation of rational heat load on absorption-ejector thermotransformer for cooling regenerative GTU intake air of compressor stations. Aerospace technics and technology, no. 5 (122), 61-64. 